\title{
Boron Biofortification of Portulaca oleracea L. through Soilless Cultivation for a New Tailored Crop
}

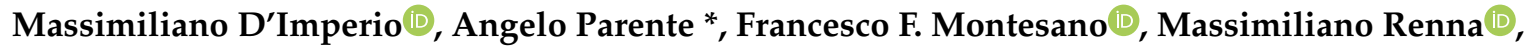 \\ Antonio F. Logrieco and Francesco Serio $\mathbb{D}$ \\ Institute of Sciences of Food Production, CNR—National Research Council of Italy, Via Amendola 122/D, 70126 \\ Bari, Italy; massimiliano.dimperio@ispa.cnr.it (M.D.); francesco.montesano@ispa.cnr.it (F.F.M.); \\ massimiliano.renna@ispa.cnr.it (M.R.); antonio.logrieco@ispa.cnr.it (A.F.L.); francesco.serio@ispa.cnr.it (F.S.) \\ * Correspondence: angelo.parente@ispa.cnr.it; Tel.: +39-080-5929-309
}

Received: 11 June 2020; Accepted: 7 July 2020; Published: 11 July 2020

Abstract: Purslane (Portulaca oleracea L.) is a wild edible plant, traditionally consumed in the Mediterranean area and recently proposed as a new ready-to-eat vegetable; it is also called the "vegetable for long life" because of the high contents of several healthy compounds. Although boron (B) is not considered to be essential for humans, a daily intake of about $2 \mathrm{mg}$ to obtain positive effects on aging in adult men and women has been suggested. In this study, two genotypes of purslane (wild collected and commercial variety) are grown by using a hydroponic system with three boron (B) levels in the nutrient solution (NS) $(0.3 \mathrm{mg} / \mathrm{L}$ - control, $3 \mathrm{mg} / \mathrm{L}$ - low level of biofortification, and $6 \mathrm{mg} / \mathrm{L}$-high level of biofortification) in order to increase the B content in the edible parts of the plant. The crop yield, color traits, and content of glucose, fructose, total phenols, chlorophylls, carotenoids, mineral elements ( $\mathrm{Al}, \mathrm{B}, \mathrm{Ca}, \mathrm{Cr}, \mathrm{Fe}, \mathrm{K}, \mathrm{Mg}, \mathrm{Mn}, \mathrm{Na}$, and $\mathrm{Zn}$ ), nitrate, and oxalate are analyzed. Independent of the genotype, the $\mathrm{B}$ content in edible purslane was successfully increased in comparison with the control, obtaining 1.8- to 10.7-fold higher values of B tissue concentrations by using, respectively, 3 and $6 \mathrm{mg} / \mathrm{L}$ of B in the NS without affecting crop performances. From a nutritional point of view, the average daily intake of $B$ could be satisfied by consuming about 75 or $48 \mathrm{~g}$ of purslane, grown by using 3 and $6 \mathrm{mg} / \mathrm{L}$ B level in the NS, respectively. Apart from B and $\mathrm{Fe}$, the content of mineral elements in edible parts of purslane was not strongly influenced by different $B$ levels in the NS but it was affected by genotypes. A lower sugar content was found in wild purslane grown with the highest B level. A higher content of both chlorophylls and carotenoids was found in the control but only for the commercial genotype. No differences in oxalate content were observed among B levels in the NS, while only in the case of wild genotype, we found a lower nitrate content when a B concentration of $3 \mathrm{mg} / \mathrm{L}$ was used in the NS. In conclusion, we demonstrated the possibility of using the floating hydroponic system, combined with specific $B$ concentrations in the NS composition, as a method to calibrate the B uptake in edible parts of purslane.

Keywords: color traits; crop performance; floating system; mineral elements; nitrate; oxalate; Portulaca oleracea $\mathrm{L}$; wild vegetables

\section{Introduction}

Increasing evidences suggest that healthy eating, based on the adequate consumption of plant-based foods, plays an important role in the prevention of many chronic diseases, such as heart disease, cancer, stroke, diabetes, Alzheimer's disease, and age-related functional decline [1-4]. Vegetables represent one of the most important nutrient sources in the human diet, although their nutritional value is related to several aspects such as species, cultivar, growing conditions, and production methods. 
Purslane (Portulaca oleracea L.), a wild edible plant endemic to the Mediterranean area [5,6], has been proposed as a new ready-to-eat vegetable product [7]. This species shows interesting nutritional traits, with particular reference to its high content of several healthy compounds such as mineral elements and $\omega-3$ fatty acids, especially $\alpha$-linoleic acid $[6,8]$. Furthermore, it is a vegetable with a very interesting $\omega-6: \omega-3$ ratio (less than 2 ), which has been confirmed to be of major importance for ensuring the proper equilibrium between these two types of essential fatty acids in human body, and consequently for contributing to a good health of the cardiovascular system [8]. Furthermore, it should be considered that the uptake of $\omega-3$ fatty acids is known for its positive effect on bone health [9]. It is interesting to note that, in certain regions, purslane is also traditionally called the "vegetable for long life", due to its high amounts of dopamine and catecholamine, which has proven useful to prevent cancer and heart related diseases [5].

For the above-mentioned nutritional characteristics, purslane is gaining interest as a healthy vegetable, and it has already been proposed as a target species to obtain vegetable products with improved nutritional value through plant biofortification techniques aimed at enriching plant tissue with specific elements [10].

Boron (B), an element contained in several foods such as fruits, leafy vegetables, legumes, nuts, wine, and beer is not considered to be an essential human nutrient [11]. Nevertheless, there are some evidences regarding the beneficial effects of B intake for humans on Ca metabolism and bone health, probably due to the effects of $B$ on the increased efficiency in the utilization of vitamin $D[12,13]$. It is interesting to note that B can prevent vitamin D deficiency [12] and increase the levels of steroid hormones in serum by influencing their metabolism [14]. Although boron-recommended intakes for humans are not officially provided, [15] reported that an intake between 1.0 and $3.0 \mathrm{mg}$ B per day could be considered adequate to obtain positive effects on aging prevention and longevity.

Although a specific biochemical function of B has not been identified in plants [16], this element is considered to be essential for vegetable growth [17]. Actually, B is frequently supplied as a foliar fertilizer to improve the nutritional quality of rice [18] and as an element of nutrient solution (NS) for growing soilless vegetables [19]. At the same time, it should be considered that a high B intake in plants, in relation to high concentrations in soil, growing substrate, and/or fertilization practice, could induce toxicity symptoms such as chlorosis and necrosis of leaves as well as the inhibition of plant growth [20]. It is interesting to highlight that the use of soilless systems allows to accurately dose the amount of each element in the NS, potentially avoiding any excess or deficiency of nutrients in plants. Furthermore, by acting on the mineral composition of the NS, it is possible to increase or reduce the concentration of target ions in plant tissue to obtain tailored vegetables for specific nutritional requirements [21-25]. For example, some authors $[26,27]$ reported the use of NS with different potassium (K) levels to obtain low-potassium vegetables suitable for people affected by chronic kidney disease. On the other hand, Gonnella et al.,) [22] proposed the use of iodine-biofortified Brassica vegetables for preventing iodine (I) deficiency and related human disorders, while biofortification for silicon and calcium has been proposed to obtain vegetables suitable for women in premenopausal conditions [21-23].

In a previous study, we focused on increasing the silicon content in tissue (leaves and petioles) of purslane by using soilless cultivation [10]. However, to the best of our knowledge, there is a lack of information in the literature with regard to the B biofortification of purslane. Furthermore, it is important to highlight that purslane shows a high genetic variability which translates into a potential variability of different agronomic traits $[28,29]$. In this context, it should be considered that for a successful application of the biofortification strategy, the evaluation of several aspects of the process in relation to different genotype-related traits may be opportune.

Starting from these remarks, the aims of the present study are: (i) to increase the B content in edible parts of purslane without negatively affect crop performance, (ii) to evaluate the effects of different $B$ levels on the content of healthy compounds and anti-nutritional factors in two different genotypes (wild and commercial) of purslane. The general goal is to verify the possibility of using 
the floating hydroponic system as a method to calibrate the B uptake in purslane plants to obtain a tailored boron content in edible parts.

\section{Materials and Methods}

\subsection{Plant Materials and Experimental Conditions}

Two experiments were conducted in a plastic greenhouse located at the experimental farm "La Noria" of the Institute of Sciences of Food Production (ISPA-CNR) in Mola di Bari (BA), Southern Italy ( $41^{\circ} 03^{\prime} \mathrm{N}, 17^{\circ} 04^{\prime} \mathrm{E} ; 24 \mathrm{~m}$ a.s.l.). The first experiment was carried out from 29 June to $29 \mathrm{July}$, 2016, while the second experiment was carried out from 13 June to 7 July, 2017. Mean air temperature, relative humidity, and photosynthetically active radiation (PAR) inside the greenhouse during the experiments were: $29{ }^{\circ} \mathrm{C}, 53 \%$, and $221.6 \mu \mathrm{mol} / \mathrm{m}^{2} / \mathrm{sec}$ (first experiment) and $30{ }^{\circ} \mathrm{C}, 47 \%$, and 210.1 $\mu \mathrm{mol} / \mathrm{m}^{2} / \mathrm{sec}$ (second experiment), respectively. Two different populations of purslane were used: the seeds of wild plants harvested in Policoro (Matera) for the first experiment and commercial seed purchased from the Riccardo Larosa Company (Andria, Italy) for the second experiment.

The seeds were sown in a cell pot containing peat. When seedlings reached the two-true leaves stage (after seven and six days from sowing, respectively, for the first and second experiments) the cell pots were moved on a floating hydroponic system, where plants were grown up to the end of the experiments. An NS composed of rain water, $\mathrm{N}\left(140 \mathrm{mg} / \mathrm{L}-\mathrm{NO}_{3}-\mathrm{N}: \mathrm{NH}_{4}-\mathrm{N}\right.$ at a percentage ratio of 80:20), $\mathrm{P}(50 \mathrm{mg} / \mathrm{L}), \mathrm{K}(200 \mathrm{mg} / \mathrm{L}), \mathrm{Mg}(40 \mathrm{mg} / \mathrm{L}), \mathrm{S}(102 \mathrm{mg} / \mathrm{L})$, and $\mathrm{Ca}(100 \mathrm{mg} / \mathrm{L})$ was used. Micronutrients were added according to [19], with slight modifications based on the common practice. Boron was added as boric acid to the NS at different concentrations according to the treatments- $0.3,3$, and $6 \mathrm{mg} / \mathrm{L}$-corresponding to a control $(0.3 \mathrm{mg} / \mathrm{L})$ and two levels of $B$ biofortification $(3 \mathrm{and} 6 \mathrm{mg} / \mathrm{L}$ ). The NS $\mathrm{pH}$ was measured every three days and it was adjusted to 5.5-6.0 using $1 \mathrm{M} \mathrm{H}_{2} \mathrm{SO}_{4}$. Moreover, an air pump was used in order to promote oxygenation of the NS and avoid possible root anoxia issues. A randomized complete block design with three replications was used. Each replication constituted of 576 plants.

\subsection{Yield, Dry Weight, and Color Analysis}

At the harvest (phenological stage of fourth to fifth true leaf, defined as "baby leaf", as reported by Di Gioia et al., [30]), 30 days for the 1st experiment and 24 days after sowing for the 2 nd experiment. The yield (expressed as $\mathrm{g}$ of fresh weight (FW)/plant) was obtained by collecting 24 plants for each replicate (Figure 1).

For the measurement of dry weight (DW) in edible parts, fresh samples were maintained in a forced draft oven at $65^{\circ} \mathrm{C}$ until a constant weight was reached. At harvest, the roots of purslane were harvested and abundantly washed with ultrapure $\mathrm{H}_{2} \mathrm{O}$ (Milli-Q Millipore $18 \mathrm{M} \Omega / \mathrm{cm}$ ) in order to remove the residue of NS and successively maintained in a forced draft oven at $65^{\circ} \mathrm{C}$ until a constant weight was reached.

Color parameters $\left(L, a^{*}\right.$ and $\left.b^{*}\right)$ were measured on the peel surface of ten leaves per replicate with a colorimeter (CR-400, Konica Minolta, Osaka, Japan) in reflectance mode using the CIELab color scale. Before the measurements, the colorimeter was calibrated with a standard reference with $L, a^{*}$, and $b^{*}$ values of $97.55,1.32$, and 1.41 , respectively. Hue angle $\left[h^{\circ}=\tan ^{-1}\left(b^{*} / a^{*}\right)\right]$ and saturation or chroma $\left[C=\left(a^{* 2}+b^{* 2}\right)^{1 / 2}\right]$ were then calculated from the primary readings. 

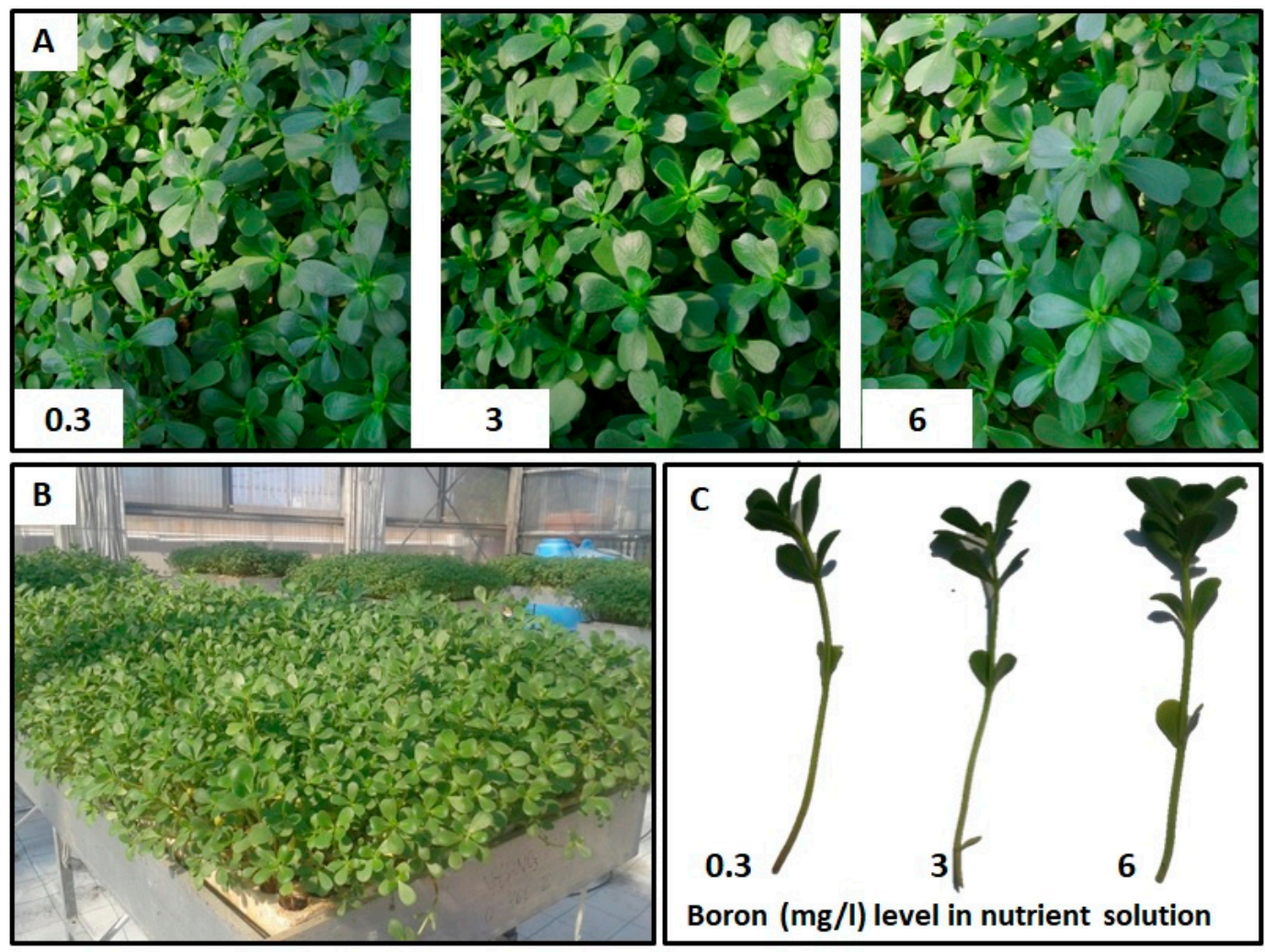

Figure 1. Wild (A) and commercial (B and C) purslane (Portulaca oleracea L.) cultivated with three different levels of Boron in nutrient solution.

\subsection{Samples Preparation for Chemical Analysis}

For each replication, purslane samples were freeze-dried by a LABCONCO FreeZone ${ }^{\circledR}$ Freeze Dry System, model 7754030, (Kansas City, MI, USA) equipped with a LABCONCO FreeZone ${ }^{\circledR}$ Stoppering Tray Dryer, model 7,948,030 (Kansas City, MI, USA). The freeze-dried samples were ground at $500 \mu \mathrm{m}$ by using a Retsch laboratory mill (Torre Boldone, BG, Italy) to obtain a homogeneous powder.

\subsection{Glucose and Fructose Contents}

Glucose and fructose contents were determined by ion chromatography (Dionex DX500, Dionex Corporation, Sunnyvale, CA, USA) using a pulsed amperometric detector (PAD) according to the protocol used by Renna et al., [31]. Peak separation was performed using a Dionex CarboPac PA1 separation column (Dionex Corporation) and isocratic elution with $50 \mathrm{mmol} / \mathrm{L} \mathrm{NaOH}$.

\subsection{Extraction and Analysis of Total Phenols, Chlorophylls, and Carotenoids}

The total phenol (TP) content was determined according to the Folin-Ciocalteu method by using the extraction methods reported by D'Imperio et al., (2019) [27]. Briefly, $200 \mathrm{mg}$ of lyophilized sample were mixed with $10 \mathrm{~mL}$ of solvent mixture (MeOH: $\left.\mathrm{H}_{2} \mathrm{O}: \mathrm{CH}_{3} \mathrm{COOH}, 79: 20: 1 \% v / v / v\right)$. The vials were then placed in a sonicator bath at ambient temperature for $30 \mathrm{~min}$, followed by $1 \mathrm{~h}$ in a magnetic stirrer. The mixture was centrifuged at $10,000 \times g$ at $4{ }^{\circ} \mathrm{C}$ for $10 \mathrm{~min}$ and the supernatant was transferred into a volumetric tube. The residue was resuspended in $10 \mathrm{~mL}$ of $\mathrm{MeOH}: \mathrm{H}_{2} \mathrm{O}: \mathrm{CH}_{3} \mathrm{COOH}$ (79:20:1\% $v / v / v)$, gently mixed manually, and sonicated for an additional $30 \mathrm{~min}$, followed by stirring $(1 \mathrm{~h})$ and centrifugation $\left(10,000 \times g\right.$ at $\left.4{ }^{\circ} \mathrm{C} 10 \mathrm{~min}\right)$. The TP content was determined using gallic acid $\left(R^{2}=0.9991\right)$ as a calibration standard by using a Perkin-Elmer Lambda 25 spectrophotometer (Boston, MA, USA).

Chlorophylls and total carotenoid content were determined spectrophotometrically, using the extraction procedure reported by Montesano et al., (2018) [32]. Briefly, lyophilized samples were homogenized in a fresh solution of $80 \%$ acetone $\left(\mathrm{C}_{3} \mathrm{H}_{6} \mathrm{O}: \mathrm{H}_{2} \mathrm{O}, \mathrm{v} / \mathrm{v}\right)$ and stirred for $24 \mathrm{~h}$ at room 
temperature. After extraction, the samples were diluted and filtered by using $0.45 \mu \mathrm{m}$ (regenerated cellulose, RC) and the absorbance of the extracts were measured at 662, 645 and $470 \mathrm{~nm}$, using a UV-1800 spectrophotometer (Perkin-Elmer Lambda 25 spectrophotometer, Boston, MA, USA).

\subsection{Minerals and Anions Analysis Purslane Samples}

For $\mathrm{Al}, \mathrm{B}, \mathrm{Ca}, \mathrm{Cr}, \mathrm{Fe}, \mathrm{K}, \mathrm{Mg}, \mathrm{Mn}, \mathrm{Na}$, and $\mathrm{Zn}$ determination, $0.3 \mathrm{~g}$ of dried sample were accurately weighted in microwave digestion vessels followed by the addition of $10 \mathrm{~mL}$ of $65 \% \mathrm{HNO}_{3}$ (Pure grade, Carlo Erba) and digested in a closed-vessel microwave assisted digestion system (MARS 6, CEM Corporation, Matthews, NC, USA). The digestion procedure was performed in two steps: $15 \mathrm{~min}$ to reach $200{ }^{\circ} \mathrm{C}$ and $10 \mathrm{~min}$ maintained at $200{ }^{\circ} \mathrm{C}$ (power set at $900-1050 \mathrm{~W} ; 800 \mathrm{psi}$ ). The digested solutions were cooled and quantitatively transferred to a $50 \mathrm{~mL}$ volumetric flask. Each solution was diluted to volume with ultrapure $\mathrm{H}_{2} \mathrm{O}$ (Milli-Q Millipore $18 \mathrm{M} \Omega / \mathrm{cm}$ ) and filtered using a $0.45 \mu \mathrm{m}$ filter.

Samples were analyzed with a Inductively Coupled Plasma-Optical Emission Spectrometry (ICP-OES; 5100 VDV, Agilent Technologies, Santa Clara, CA, USA) to measure Ca, K, Mg, and Na in radial mode and $\mathrm{Al}, \mathrm{B}, \mathrm{Fe}, \mathrm{Mn}, \mathrm{Zn}, \mathrm{Al}$, and $\mathrm{Cr}$ in axial mode [33].

For nitrate and oxalate determinations, ion exchange chromatography (Dionex DX120, Dionex Corporation, Sunnyvale, CA, USA) with a conductivity detector was used as reported by D'Imperio et al., (2018) [33]. Briefly, the nitrate and oxalate were extracted from DW samples with $3.5 \mathrm{mM}\left(\mathrm{Na}_{2} \mathrm{CO}_{3}\right)$ and $1 \mathrm{mM}\left(\mathrm{NaHCO}_{3}\right)$ for $30 \mathrm{~min}$. After extraction, the samples were diluted and filtered by using $0.45 \mu \mathrm{m}(\mathrm{RC})$ followed by Dionex OnGuard IIP (ThermoScientific). The resulting solutions were analyzed by ion chromatography (IC-Dionex DX120, Dionex Corporation) with a conductivity detector by using an IonPac AG14 precolumn and an IonPac AS14 separation column (Dionex Corporation).

\subsection{Statistical Analysis}

The effects of different treatments were tested using a one-way analysis of variance (ANOVA) followed by means separation using Fisher's protected least-significant difference (LSD) at $p=0.05$. The statistical software Statistica 10.0 (StatSoft, Tulsa, OK, USA) was used for the analysis.

\section{Results}

No differences were found in the first experiment as regards yield, dry weight (DW), and color parameters at increasing B level in the NS. The average values of yield and DW were, respectively, $16.22 \mathrm{~g} /$ plant and $6.69 \mathrm{~g} / 100 \mathrm{FW}$, while $L, a^{*}, b^{*}, \mathrm{~h}^{\circ}$, and C average values were, respectively, 42.76, $-13.01,18.76,124.75$, and 22.83 (Table 1). In the second experiment, the average values of yield and dry weight were $13.2 \mathrm{~g} /$ plant and $4.9 \mathrm{~g} / 100 \mathrm{~g}(\mathrm{FW})$, respectively, with no differences among treatments (Table 1). By using both high and low boron level in the NS, the $L$ value was $3 \%$ higher than the control, while the average values of $a^{*}, b^{*} h^{\circ}$, and C were, respectively, $-10.9,15.06,125.89$, and 18.59, with no differences among treatments (Table 1 ).

By using 3 and $6 \mathrm{mg} / \mathrm{L}$ of B in the NS, the B tissue content in wild purslane increased, respectively, 6.5- and 10.7-fold with respect to the control (Figure 2A), without causing any symptoms of toxicity in plants. In the second, by using 3 and $6 \mathrm{mg} / \mathrm{L}$ of B in the NS, the B content in commercial purslane increased, respectively, 1.85- and 2.74-fold compared to the control (Figure 2B), without causing symptoms of toxicity in plants. 
Table 1. Effects of different boron level in the nutrient solution on yield, dry weight, and color traits in edible parts of wild (first experiments) and commercial (second experiment) purslane.

\begin{tabular}{|c|c|c|c|c|c|c|c|}
\hline $\begin{array}{l}\text { Boron } \\
\text { Level }\end{array}$ & Yield & Dry Weight & $L$ & $a^{*}$ & $b^{*}$ & $\mathbf{h}^{\circ}$ & $\mathrm{C}$ \\
\hline $\mathrm{mg} / \mathrm{L}$ & $\mathrm{g} /$ plant & $\mathrm{g} / 100$ of $\mathrm{FW}$ & & & & & \\
\hline 0.3 & $15.33 \pm 0.32$ & $7.12 \pm 0.52$ & $42.67 \pm 0.89$ & $-13.13 \pm 0.52$ & $18.90 \pm 1.57$ & $124.81 \pm 1.42$ & $23.02 \pm 1.55$ \\
\hline 3 & $17.71 \pm 1.76$ & $7.14 \pm 0.21$ & $42.75 \pm 0.78$ & $-12.92 \pm 0.46$ & $18.25 \pm 0.58$ & $125.32 \pm 0.73$ & $22.36 \pm 0.68$ \\
\hline 6 & $15.62 \pm 0.32$ & $6.63 \pm 0.23$ & $42.86 \pm 0.20$ & $-12.97 \pm 0.29$ & $19.13 \pm 0.56$ & $124.14 \pm 0.51$ & $23.11 \pm 0.60$ \\
\hline \multicolumn{8}{|c|}{ Second experiment } \\
\hline 0.3 & $13.40 \pm 1.6$ & $4.66 \pm 0.33$ & $40.71 \pm 0.28 b$ & $-10.67 \pm 0.17$ & $14.94 \pm 0.46$ & $125.55 \pm 0.96$ & $18.36 \pm 0.39$ \\
\hline 3 & $14.73 \pm 2.1$ & $5.16 \pm 0.83$ & $41.99 \pm 0.66 \mathrm{a}$ & $-11.25 \pm 0.59$ & $15.44 \pm 0.65$ & $126.08 \pm 1.0$ & $19.11 \pm 0.82$ \\
\hline 6 & $13.22 \pm 0.6$ & $5.01 \pm 014$ & $42.11 \pm 0.41 \mathrm{a}$ & $-10.77 \pm 0.1$ & $14.80 \pm 0.28$ & $126.03 \pm 0.44$ & $18.31 \pm 0.25$ \\
\hline Significance & ns & ns & $* *$ & ns & ns & Ns & ns \\
\hline
\end{tabular}

Different letters within each column and experiment indicate that mean values are significantly different, according to the Least Significant Difference $(\alpha=0.05)$. Significance: $\mathrm{ns}=$ not significant; ${ }^{* *} p \leq 0.01 \mathrm{FW}$ : fresh weight.
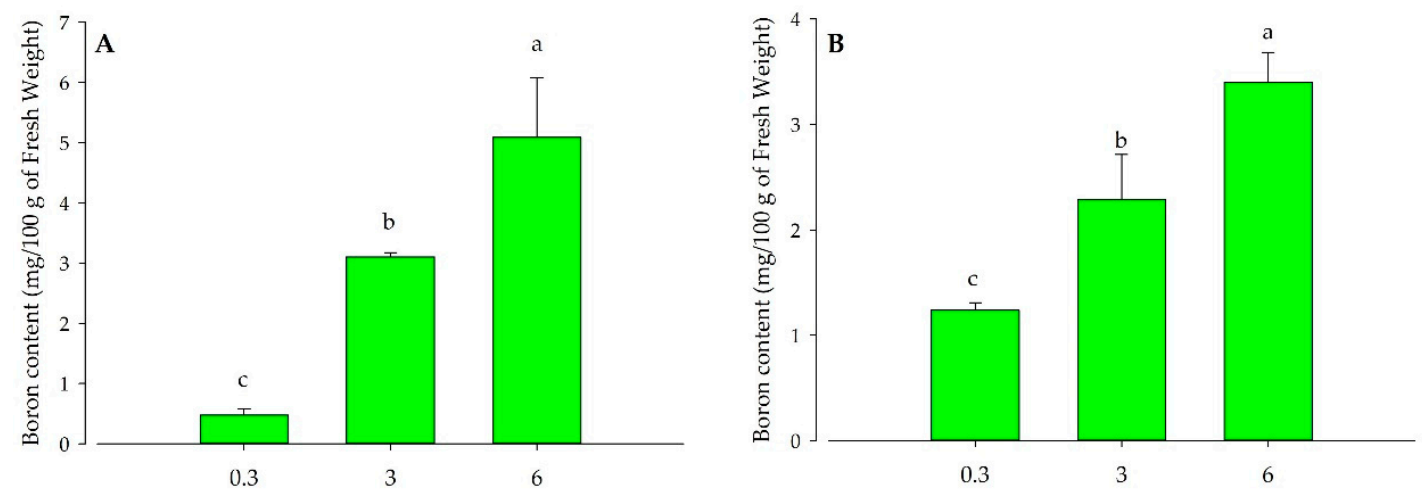

Figure 2. Boron content in edible parts of wild (A: firsxperiment) and commercial (B: second experiment) purslane, as affected by different boron levels in the nutrient solution, control $(0.3 \mathrm{mg} / \mathrm{L})$, and two levels of B biofortification ( 3 and $6 \mathrm{mg} / \mathrm{L}$ ). Different letters indicate that mean values are significantly different, according to the Least Significant Difference $(\alpha=0.05)$.

As regards $\mathrm{Ca}$, no differences were observed between the control and treatments. With respect to $\mathrm{Fe}$, the highest content was found in purslane fertigated by using $3 \mathrm{mg} / \mathrm{L}$ of $\mathrm{B}$, resulting in being $122.9 \%$ higher than the control and $6 \mathrm{mg} / \mathrm{L}$ of B. Zinc content was highest in the control, resulting in being 53.2 and $10.3 \%$ higher than high and low B levels, respectively (Table 2). The average contents of $\mathrm{K}, \mathrm{Mg}$, $\mathrm{Na}$, and $\mathrm{Mn}$ were $74.74,7.78,0.458$, and $0.102 \mathrm{~g} / \mathrm{kg}$ of DW, respectively, with no differences among treatments. The $\mathrm{Al}$ and $\mathrm{Cr}$ were low with respect to the limit of quantification (LOQ), as reported in Table 2.

In the second experiment, the use of $3 \mathrm{mg} / \mathrm{L}$ of B in the NS allowed to obtain an Fe content 2.9-fold higher than other treatments, while the highest Mn content was found in the control, resulting in being $34 \%$ higher than other treatments (Table 2). The average contents of $\mathrm{Ca}, \mathrm{K}, \mathrm{Mg}, \mathrm{Na}$, and $\mathrm{Zn}$ were, respectively, of $11.86,84.53,7.54,2.12$, and $0.14 \mathrm{~g} / \mathrm{kg} \mathrm{DW}$, without differences among treatments (Table 2). Furthermore, in this case, $\mathrm{Al}$ and $\mathrm{Cr}$ were low with respect to the limit of quantification (Table 2). 
Table 2. Effects of different boron level in the nutrient solution the content of $\mathrm{Ca}, \mathrm{K}, \mathrm{Mg}, \mathrm{Na}, \mathrm{Fe}, \mathrm{Mn}$, and $\mathrm{Zn}$ in edible parts of wild (first experiment) and commercial (second experiment) purslane.

\begin{tabular}{|c|c|c|c|c|c|c|c|}
\hline $\begin{array}{l}\text { Boron } \\
\text { Level }\end{array}$ & $\mathrm{Ca}$ & $\mathbf{K}$ & $\mathrm{Mg}$ & $\mathrm{Na}$ & $\mathrm{Fe}$ & Mn & $\mathrm{Zn}$ \\
\hline $\mathrm{mg} / \mathrm{L}$ & \multicolumn{4}{|c|}{$\mathrm{g} / \mathrm{kg}$ of DW } & \multicolumn{3}{|c|}{$\mathrm{mg} / \mathrm{kg}$ of DW } \\
\hline 0.3 & $10.26 \pm 0.3 \mathrm{ab}$ & $75.77 \pm 4.72$ & $7.99 \pm 1.28$ & $0.470 \pm 0.1$ & $24.54 \pm 4.27 b$ & $107.86 \pm 25.2$ & $83.33 \pm 8.47 a$ \\
\hline 3 & $9.21 \pm 0.57 b$ & $71.54 \pm 1.91$ & $7.52 \pm 0.33$ & $0.460 \pm 0.1$ & $51.20 \pm 5.8 \mathrm{a}$ & $100.80 \pm 0.92$ & $54.40 \pm 7.60 \mathrm{c}$ \\
\hline 6 & $11.11 \pm 0.55 \mathrm{a}$ & $76.92 \pm 0.40$ & $7.83 \pm 1.42$ & $0.445 \pm 0.2$ & $21.40 \pm 2.6 \mathrm{~b}$ & $99.53 \pm 18.41$ & $75.53 \pm 11.7 b$ \\
\hline \multicolumn{8}{|c|}{ Second experiment } \\
\hline 0.3 & $11.91 \pm 1.3$ & $88.50 \pm 8.8$ & $7.29 \pm 0.78$ & $1.98 \pm 0.12$ & $314.94 \pm 68 b$ & $217.13 \pm 47 \mathrm{a}$ & $119.54 \pm 5.6$ \\
\hline 3 & $10.39 \pm 1.8$ & $76.52 \pm 10.6$ & $7.37 \pm 0.16$ & $2.12 \pm 0.23$ & $958.21 \pm 215 a$ & $168.73 \pm 21 b$ & $151.70 \pm 23.6$ \\
\hline 6 & $13.32 \pm 0.36$ & $88.56 \pm 4.0$ & $7.95 \pm 0.26$ & $2.25 \pm 0.26$ & $316.95 \pm 47 b$ & $155.37 \pm 11 b$ & $138.64 \pm 15.6$ \\
\hline Significance & ns & ns & ns & ns & $*$ & $*$ & ns \\
\hline
\end{tabular}

Different letters within each column and experiment indicate that mean values are significantly different, according to the Least Significant Difference $(\alpha=0.05)$. Significance: ns $=$ not significant; ${ }^{*} p \leq 0.05 ;{ }^{* *} p \leq 0.001$. DW: dry weight. $\mathrm{Al}$ and $\mathrm{Cr}<$ limits of quantification (LOQ), 1.1 and $0.82 \mathrm{mg} / \mathrm{kg}$ dry matter respectively. The LOQ of the method was calculated as follows: $10 \times$ mean of standard deviation (n. 15).

Purslane fertigated by using $3 \mathrm{mg} / \mathrm{L}$ of B level showed the lowest content of nitrate, resulting $32 \%$ lower than other samples (Table 3). The average oxalate concentration was $4.73 \mathrm{~g} / \mathrm{kg} \mathrm{FW}$ with no differences among treatments, while the content of glucose and fructose decreased, respectively, of $38 \%$ and $32 \%$ by using high $\mathrm{B}$ level (Table 3 ). In the second experiment, the average values of $\mathrm{NO}_{3}$, oxalate, glucose and fructose were, respectively, of $0.32,4.08,1.63$, and $1.53 \mathrm{~g} / \mathrm{kg}$ FW, without differences among treatments (Table 3).

Table 3. Effects of different boron levels in the nutrient solution on the content of nitrate, oxalate, glucose, and fructose in edible parts of wild (first experiment) and commercial (second experiment) purslane.

\begin{tabular}{|c|c|c|c|c|}
\hline Boron Level & $\mathrm{NO}_{3}$ & Oxalate & Glucose & Fructose \\
\hline $\mathrm{mg} / \mathrm{L}$ & \multicolumn{4}{|c|}{ g/kg FW } \\
\hline \multicolumn{5}{|c|}{ First experiment } \\
\hline 0.3 & $0.33 \pm 0.03 a$ & $4.8 \pm 0.47$ & $4.90 \pm 1.06 \mathrm{a}$ & $3.79 \pm 0.35 a$ \\
\hline 3 & $0.23 \pm 0.02 b$ & $4.55 \pm 0.11$ & $4.65 \pm 027 \mathrm{a}$ & $4.06 \pm 0.44 \mathrm{a}$ \\
\hline 6 & $0.34 \pm 0.05 a$ & $4.85 \pm 0.42$ & $2.94 \pm 0.31 b$ & $2.67 \pm 0.22 b$ \\
\hline Significance & $*$ & ns & $*$ & $* *$ \\
\hline \multicolumn{5}{|c|}{ Second experiment } \\
\hline 0.3 & $0.37 \pm 0.04$ & $3.86 \pm 0.39$ & $2.01 \pm 0.27$ & $1.68 \pm 0.21$ \\
\hline 3 & $0.28 \pm 0.02$ & $4.41 \pm 0.65$ & $1.25 \pm 0.98$ & $1.31 \pm 0.18$ \\
\hline 6 & $0.29 \pm 0.01$ & $3.96 \pm 0.26$ & $1.64 \pm 0.19$ & $1.60 \pm 0.03$ \\
\hline Significance & ns & ns & ns & ns \\
\hline
\end{tabular}

Different letters within each column and experiment indicate that mean values are significantly different, according to the Least Significant Difference $(\alpha=0.05)$. Significance: $\mathrm{ns}=$ not significant; ${ }^{*} p \leq 0.05 ; * * p \leq 0.01$. FW: fresh weight.

In the first experiment, the highest total phenol content was found in control conditions, resulting in being 34.5\% higher than other treatments, while the average values of CHLa, CHLb, CHLtot, and carotenoids were $7.31,1.14,8.45$, and $2.59 \mathrm{mg} / 100 \mathrm{~g}$ of $\mathrm{FW}$, respectively, with no differences among treatments (Table 4). In the second experiment, by using both low and high B levels in the NS, the content of CHLa, CHLb, CHLt, and carotenoids decreased, respectively, of $40 \%, 55 \%, 45 \%$, and $41 \%$ compared to the control, while the average total phenol content was of $106.75 \mathrm{mg} / 100 \mathrm{~g}$ FW without differences among treatments (Table 4). 
Table 4. Effects of different boron levels in the nutrient solution on the content of total polyphenols, chlorophyll (A and B), and carotenoids in the edible parts of wild (first experiment) and commercial (second experiment) purslane.

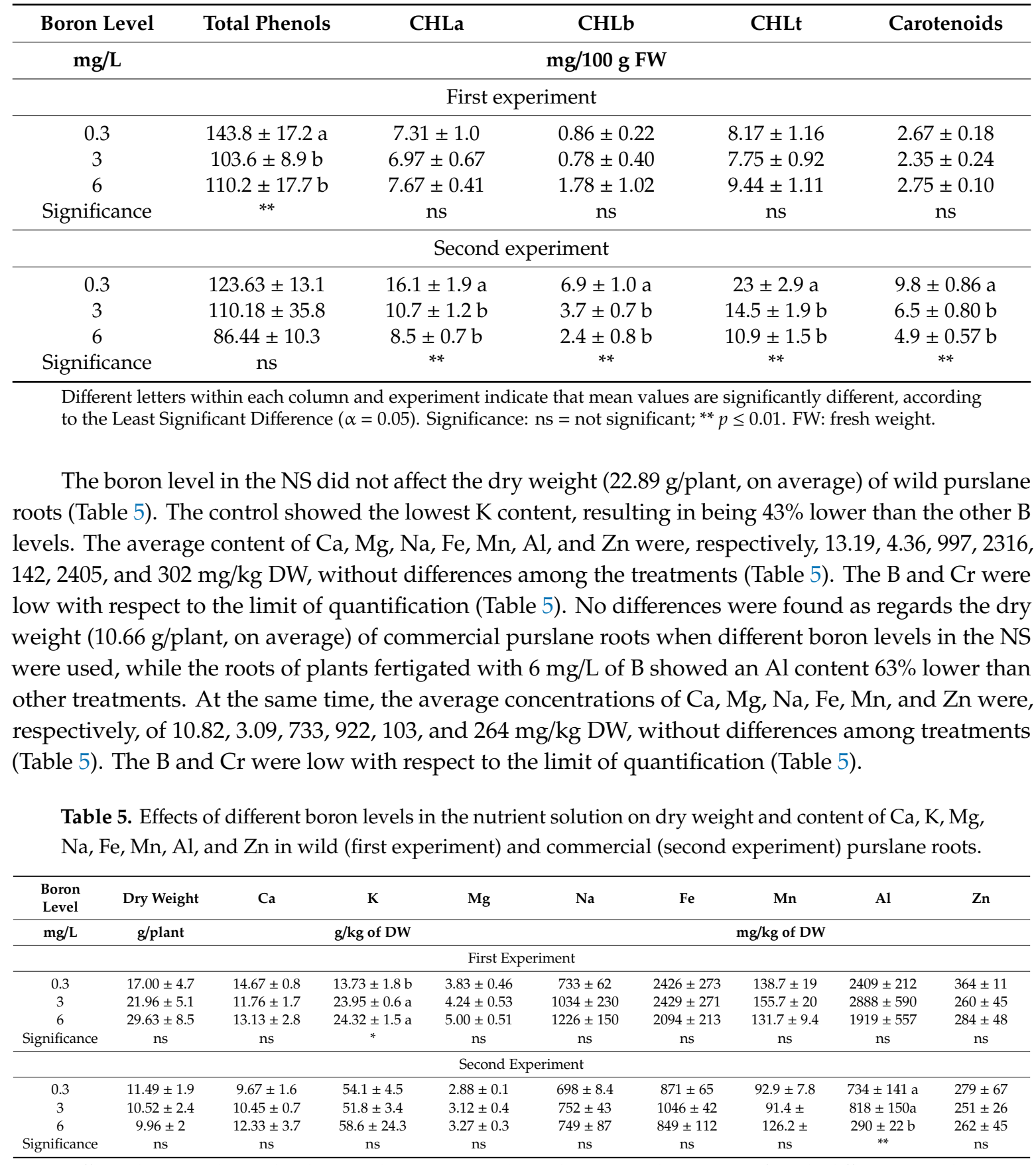

Different letters within each column and experiment indicate that mean values are significantly different, according to the Least Significant Difference $(\alpha=0.05)$. Significance: $\mathrm{ns}=$ not significant; ${ }^{*} p \leq 0.05 ;{ }^{* *} p \leq 0.01$. DW: dry weight. B and $\mathrm{Cr}<$ limits of quantification (LOQ), 1.7 and $0.82 \mathrm{mg} / \mathrm{kg}$ DW, respectively. The LOQ of the method was calculated as follows: $10 \times$ mean of standard deviation (n. 15).

\section{Discussion}

The present study reports scientific evidences on the effectiveness of a cultivation process, based on a soilless system combined with specific B concentrations in the NS, for the B biofortification of purslane. Taking into consideration the high genetic variability intrinsic in this species [28,29], the possibility to obtain a B enrichment in edible parts was tested over two different genotypes (wild and commercial) of P. oleracea L. 
Increasing B levels in the NS significantly boosted the B content in edible parts of purslane (Figure 2) with no differences in yield and DW (Table 1). Our results are in agreement with several authors [34-39], who reported significant increases of B in different species as a consequence of high concentrations of this element in growing media and/or NS. In fact, B moves from the roots with the transpiration stream and accumulates in growing points of leaves and stems [40]. In addition, the transport of $B$ from roots to shoots increased linearly according to the increase in the concentration of $B$ in the rooting medium [17].

Nevertheless, it should be considered that in response to high B levels [38,39], a yield reduction and symptoms of toxicity in purslane plants was observed. Landi et al. [37] observed a strong reduction of yield and DW as well as symptoms of toxicity also in basil plants by using $20 \mathrm{mg} / \mathrm{L}$ of B in the NS, although this concentration promoted B uptake in the edible parts of two basil cultivars. In our study, no visible symptoms of toxicity in plants were observed, and no differences of color parameters were detected, with the exception of little $L$ value variation in the second experiment (Table 1 ). This indicates that the color of boron-enriched purslane is almost similar to the control. Therefore, since color, yield, and DW are important traits for assessing crop performance, the results of the present study suggest that the boron biofortification of purslane is effective at a concentration of 3-6 mg/L in the NS without negatively affecting crop performance.

From a nutritional point of view, it should be considered that although $B$ is not considered to be essential for humans [11], some authors [13,15,41] suggested an average daily intake of B of about $2 \mathrm{mg}$ in order to improve bone health. In our study, we found an average B content of 2.69 and $4.24 \mathrm{mg} 100 \mathrm{~g} \mathrm{FW}$, respectively, in purslane grown by using 3 and $6 \mathrm{mg} / \mathrm{L}$ of $\mathrm{B}$ in the NS (Figure 2). Therefore, the suggested intake of B could be satisfied by consuming about $75 \mathrm{~g}$ or $48 \mathrm{~g}$, respectively, of purslane grown by using 3 and $6 \mathrm{mg} / \mathrm{L}$ of boron in the NS. Rouphael et al. [42] suggested that the management of the NS composition in soilless systems can be considered an important strategy for improving the nutritional quality of vegetable products. By using $3 \mathrm{mg} / \mathrm{l}$ of B in the NS, we found the highest Fe content in the edible parts of purslane, resulting in being about 2.5-fold higher than the other treatments (Table 2). These results are in agreement with Parks et al. [43] who found that Fe concentration in tomato leaves increased by increasing the B supply to a certain extent, while a further increase in B caused a decrease in Fe concentration. On the other hand, no differences in $\mathrm{Fe}$ concentration were observed in leaves of maize and sunflower by increasing the B supply $[44,45]$. Therefore, it is likely that the Fe concentration in leaves at different B levels depends on the species. At the same time, in our second experiment (commercial seed), we found an average Fe content about 10-fold higher than the first experiment (seed of wild plants). In this regard, it is interesting to note that also Petropoulos et al. [29] found a great variability in Fe content among six genotypes of purslane (from 0.16 to $2.34 \mathrm{mg} / 100 \mathrm{~g} \mathrm{FW}$ ). Therefore, our results suggest that the Fe content in purslane is strongly affected by both the genotype and level of supplied B. As regards $\mathrm{Zn}$, we observed different contents in the edible parts of purslane by varying the B level in the NS but only in the first experiment (Table 2). At the same time, only in the second experiment, we observed a higher Mn content in the control than other treatments (Table 2). For all other mineral elements, no differences were found in the edible parts of purslane (Table 2). These results suggest that, with the exception of Fe, the content of mineral elements in the edible parts of purslane is not or slightly influenced by different $B$ levels in the NS but can be affected by genotypes. Furthermore, Petropoulos et al. [29] showed some differences in mineral composition among six genotypes of purslane, while by increasing B levels during purslane growth only little differences in some mineral elements were found by other authors [38,39]. Likewise, also the content of mineral elements in purslane roots was unaffected by different B levels in the NS with the exception of $\mathrm{K}$ in the first experiment (lower content in control than other treatments) and $\mathrm{Al}$ in the second experiment (lower content in $6 \mathrm{mg} / \mathrm{l}$ of B level than other treatments-Table 5). The literature lacks information regarding the effects of different $B$ levels on mineral element content in purslane roots. The boron level did not affect the root growth in our study (Table 5), these results confirm the absence of toxicity for purslane by using the B levels proposed in this study. A lower 
root mass in purslane was observed by some authors [38,39], when excess B levels were applied. In addition, it is interesting to note that the ratio between shoots and roots was very different between the two tested genotypes (0.6 in the wild and 1.4 in the commercial), confirming the fact that a wild genotype has a tendency to a greater root system as an ancestral trait aimed to improve plant tolerance to stress conditions.

In this study, we also evaluated the effect of different levels of B in the NS on the glucose and fructose content in the edible parts of purslane. Only in the first experiment, we found for both sugars a lower content in purslane grown with $6 \mathrm{mg} / \mathrm{L}$ of B compared to other B treatments (Table 3). In a study aimed to evaluate the effect of B on nitrogen metabolism and sugar levels of sugar beet, Bonilla et al. [46] found a decrease of the sugar content in leaves by increasing B concentration beyond $2.5 \mathrm{ppm}$. In agreement, our results suggest that also in purslane, B can play a role on sugar metabolism. On the other hand, it is important to note that in both experiments, no increase of sugar concentration in purslane was observed by increasing the B levels in the NS. These results confirm the absence of toxicity symptoms in plants of purslane by using the B levels proposed in this study. Yokota and Konishi [47] suggested that the accumulation of soluble carbohydrates in leaves is necessary to alleviate symptoms of toxicity due to high B concentrations.

Phenols, widely distributed in plants, represent an important group of compounds for humans, due to their antioxidant activities and ability to scavenge free radicals. In our study, only in the first experiment, we found differences among treatments, consisting in a phenol content higher in the control than purslane grown by using 3 and $6 \mathrm{mg} / \mathrm{L}$ of B (Table 4), while in the second experiment, we found an average total phenol content of $107 \mathrm{mg} / 100 \mathrm{~g}$ FW (Table 4). There is evidence that the B nutritional status of vascular plants influences the phenol metabolism and vice versa, but the specific nature of these interactions is not established [48]. In the leaves of tobacco plants grown both under B deficiency or toxicity, Ruiz et al. [49] and Chamacho-Cristobal et al. [50] both reported an increase in phenolic content. Boron forms complexes mainly with pectins and phenols in the cell wall and plasma membrane, respectively, resulting in a higher stability of these structures. When the B supply is adequate, more than $60 \%$ of this element is in free form in leaves' tissues [51]. In conditions of B, excess phenols may play a role in B compartmentalization rather than in antioxidant activity [52] and improve the response of plants at B treatments.

As regards chlorophylls and carotenoid content, no differences were observed among treatments during the first experiment, while in the second experiment, we found a higher content of both total chlorophyll (23.0 mg/kg FW) and carotenoids (9.8 mg/100 g FW) in the control than in purslane grown with 3 and $6 \mathrm{mg} / \mathrm{L}$ of B (on average 12.7 and $5.7 \mathrm{mg} / 100 \mathrm{~g} \mathrm{FW}$, respectively, for total chlorophylls and carotenoids-Table 4). In a study aimed to evaluate the response of purslane to different levels of B in the growing media, [39] found no differences in chlorophyll content by using 0,5 , and $25 \mathrm{mg}$ B per $\mathrm{kg}$ of growing substrate, while a lower content was found by using $10 \mathrm{mg}$ B per $\mathrm{kg}$ of growing substrate. Furthermore, for the carotenoids, these authors found a decreased content in purslane grown with 10 $\mathrm{mg}$ B per $\mathrm{kg}$ of growing. It is important to note that these authors observed a yield reduction only when $25 \mathrm{mg} \mathrm{B}$ per $\mathrm{kg}$ of growing substrate was used. In another study [38] found an increase of chlorophyll and carotenoid content by using B levels, respectively, $\geq 16$ and $\geq 8 \mathrm{~g}$ per $\mathrm{kg}$ of growing substrate, equivalent to B levels toxic for purslane plants. The reduction of chlorophyll content founded in this study could be related with the reduction of photosynthesis as a consequence of structural damage of thylakoids. This, in turn, altered the rate of the electron transport and influenced $\mathrm{CO}_{2}$ photoassimilation, which can also be limited by stomatal reduction, as suggested by Pereira et al., [53].

Despite some interesting nutritional traits, as already outlined above, it should be considered that purslane is classified as a species rich in oxalate and nitrate, both well-known anti-nutritional factors. Oxalate intake in humans can reduce the bioavailability of some minerals such as $\mathrm{Ca}, \mathrm{Mg}, \mathrm{K}$, and $\mathrm{Fe}$, and cause the formation of kidney stones in predisposed subjects [5]. Noonan and Savage [54] reported an oxalate content in purslane ranging from 9.1 to $16.8 \mathrm{~g} / \mathrm{kg} \mathrm{FW}$, while an amount of $23.4 \mathrm{~g} / \mathrm{kg}$ FW is indicated by other authors [55]. At the same time, Charfeddine [56] found values not higher than 
$5.0 \mathrm{~g} / \mathrm{kg} \mathrm{FW}$ in purslane grown by using a floating system. In this context, it has been proposed that the accurate calibration of the $\mathrm{NO}_{3}-\mathrm{N}: \mathrm{NH}_{4}-\mathrm{N}$ ratio achievable by using hydroponic cultivation (floating system in the case of the present study) allows to reduce the synthesis of organic acids, such as oxalic ones, and/or optimize the activity of the oxalic acid oxidase avoiding a high accumulation of oxalates in leaves and stems [5]. In agreement, we found an oxalate content ranging from about 4.1 to $4.7 \mathrm{~g} / \mathrm{kg}$ FW (Table 3), without differences between B treatments, by using a $\mathrm{NO}_{3}-\mathrm{N}: \mathrm{NH}_{4}-\mathrm{N}$ ratio of 80:20.

Nitrate, per se, is relatively non-toxic, but after ingestion, its reaction products and metabolites, such as nitrite, nitric oxide, and N-nitroso compounds can negatively impact on human health [57]. Purslane is considered as a species rich in $\mathrm{NO}_{3}$, since its content generally exceed $2500 \mathrm{mg} / \mathrm{kg} \mathrm{FW}$, although wild plants of purslane gathered in Southern Italy showed a $\mathrm{NO}_{3}$ content ranging from 360 to $2100 \mathrm{mg} / \mathrm{kg}$ FW [5]. In our study we found a $\mathrm{NO}_{3}$ content not higher than $370 \mathrm{mg} / \mathrm{kg}$ FW. Furthermore, we observed the lowest $\mathrm{NO}_{3}$ content $(226 \mathrm{mg} / \mathrm{kg} \mathrm{FW})$ during the first experiment when $3 \mathrm{mg} / \mathrm{L}$ of $\mathrm{B}$ was used (Table 3). Bonilla et al. [46] found a decrease of $\mathrm{NO}_{3}$ in sugar beet leaves when the $\mathrm{B}$ level in the NS was increased from 0.05 to $2.5 \mathrm{mg} / \mathrm{L}$, while by increasing the $B$ concentration beyond $2.5 \mathrm{mg} / \mathrm{L}$, an increase of $\mathrm{NO}_{3}$ in leaves was observed. At the same time, these authors detected an increase of nitrate-reductase activity when the B level in the NS was increased from 0.05 to $2.5 \mathrm{mg} / \mathrm{L}$, while by increasing the $B$ concentration beyond $2.5 \mathrm{mg} / \mathrm{L}$, a decrease of enzyme activity was observed. Therefore, these authors hypothesized a dose-dependent specific action of B on the nitrate-reductase activity which affects $\mathrm{NO}_{3}$ accumulation or its assimilation into nitrogen organic forms. At the same time, the absence of significant differences of $\mathrm{NO}_{3}$ content between treatments during the second experiment highlights that, apart from the B availability for plants, other factors (i.e., light exposure and genotype) can play a substantial role on the nitrate-reductase activity [58,59]. In this context, it is well-known that a lower light exposure can increase the $\mathrm{NO}_{3}$ content in plants. It is possible that the average slightly higher $\mathrm{NO}_{3}$ contents in the second experiment could be also due to the lower photosynthetically active radiation measured ( 210.1 and $221.6 \mu \mathrm{mol} / \mathrm{m}^{2} / \mathrm{sec}$, respectively for second and first experiment). At any rate, it could be interesting to evaluate the $\mathrm{NO}_{3}$ content in purslane found in our study in relation to the tolerable levels for $\mathrm{NO}_{3}$ in foodstuffs. To this aim, it is important to note that regarding vegetables, the European Regulation [60] reports maximum levels of nitrate only for the "rucola" group (Eruca sativa L., Diplotaxis spp., Brassica tenuifolia L. and Sisymbrium tenuifolium L.), spinach (Spinacia oleracea L.), and lettuce (Lactuca sativa L.). The European Regulation fixed the maximum levels of 6000 and $7000 \mathrm{mg} \mathrm{NO}_{3}$ per $\mathrm{kg} \mathrm{FW}$ for "rucola" (respectively, for harvesting in the spring-summer and autumn-winter periods), 2000 and $3500 \mathrm{mg} \mathrm{NO}_{3}$ per $\mathrm{kg} \mathrm{FW}$ for spinach (respectively, for frozen and fresh products) and from 2000 to $5000 \mathrm{mg} \mathrm{NO}$ per $\mathrm{kg}$ FW for lettuce, depending on several factors such as cultivar type ("iceberg" type or other ones), growing system (in open air or under cover), and growing period (spring-summer or autumn-winter). Considering these maximum levels, our results show the successful hydroponic production of boron-biofortificated purslane with also a relatively low content of $\mathrm{NO}_{3}$.

\section{Conclusions}

In the present study, we demonstrated the possibility of using the floating hydroponic system as a method to calibrate the B uptake in edible parts of purslane by acting on B concentration in the NS. The results suggest that $B$ biofortification of purslane is effective at a concentration of $3-6 \mathrm{mg} / \mathrm{L}$ in the NS without negatively affecting crop performance. The robustness of our findings is confirmed by the fact that the proposed biofortification strategy was tested on two different purslane genotypes (wild and commercial) and the B biofortification was successful in both cases. From a nutritional point of view, the average daily intake of $B$ could be satisfied by consuming reasonably sized portions of this vegetable. The boron biofortified purslane obtained in this study can be proposed as a tailored vegetable for people with specific nutritional requirements for which B assumption is beneficial. In particular, it is important to mention that the achievements of this study on B biofortification add to those already 
achieved by this research group on the biofortification of vegetables with other elements beneficial for bone health (namely silicon and calcium).

Author Contributions: Conceptualization, A.P., M.D., and F.S.; methodology, A.P., M.D., and F.S.; crop performance measurements, M.D., F.F.M., and M.R.; chemical analysis, M.D. and A.P.; statistical analysis, A.P.; original draft preparation M.D., M.R., F.S.; writing-review and editing, M.D., F.S., F.F.M., A.F.L., M.R., and A.P.; supervision of the study, A.P., M.R., and F.S. All authors have read and agreed to the published version of the manuscript.

Funding: This research was financed by the National Research Council (CNR) project NUTR-AGE (Fondo ordinario per gli enti e le istituzioni di ricerca FOE-2019, DSB.AD004.271).

Acknowledgments: The authors thank Nicola Gentile and Roberto Schena for the technical support.

Conflicts of Interest: The authors declare no conflict of interest.

\section{References}

1. Liu, R.H. Health-promoting components of fruits and vegetables in the diet. Adv. Nutr. 2013, 4, 384S-392S. [CrossRef] [PubMed]

2. Yahia, E.M.; García-Solís, P.; Celis, M.E.M. Contribution of fruits and vegetables to human nutrition and health. In Postharvest Physiology and Biochemistry of Fruits and Vegetables; Woodhead Publishing: Duxford, UK, 2019; pp. 19-45.

3. Del Río-Celestino, M.; Font, R. The Health Benefits of Fruits and Vegetables. Foods 2020, 9, 369. [CrossRef] [PubMed]

4. Rashmi, H.B.; Negi, P.S. Phenolic acids from vegetables: A review on processing stability and health benefits. Food Res. Int. 2020, 109298. [CrossRef]

5. Gonnella, M.; Charfeddine, M.; Conversa, G.; Santamaria, P. Purslane: A review of its potential for health and agricultural aspects. Eur. J. Plant. Sci. Biotech. 2010, 4, 131-136.

6. Ceccanti, C.; Landi, M.; Benvenuti, S.; Pardossi, A.; Guidi, L. Mediterranean wild edible plants: Weeds or "new functional crops"? Molecules 2018, 23, 2299. [CrossRef]

7. Rinaldi, R.; Amodio, M.L.; Colelli, G. Effect of temperature and exogenous ethylene on the physiological and quality traits of purslane (Portulaca oleracea L.) leaves during storage. Postharvest Biol. Tech. 2010, 58, 147-156. [CrossRef]

8. Petropoulos, S.; Karkanis, A.; Martins, N.; Ferreira, I.C. Phytochemical composition and bioactive compounds of common purslane (Portulaca oleracea L.) as affected by crop management practices. Trends Food Sci. Tech. 2016, 55, 1-10. [CrossRef]

9. Casado-Díaz, A.; Santiago-Mora, R.; Dorado, G.; Quesada-Gómez, J.M. The omega-6 arachidonic fatty acid, but not the omega-3 fatty acids, inhibits osteoblastogenesis and induces adipogenesis of human mesenchymal stem cells: Potential implication in osteoporosis. Osteoporos. Int. 2013, 24, 1647-1661. [CrossRef] [PubMed]

10. D'Imperio, M.; Renna, M.; Cardinali, A.; Buttaro, D.; Santamaria, P.; Serio, F. Silicon biofortification of leafy vegetables and its bioaccessibility in the edible parts. J. Sci. Food Agric. 2016, 96, 751-756. [CrossRef]

11. European Food Safety Authority. Scientific opinion on dietetic products, nutrition and allergies on a request from the commission related to the tolerable upper intake level of boron (Sodium Borate and Boric Acid) (Question number: EFSA-Q-2003-018). EFSA J. 2004, 80, 1-22.

12. Hunt, C.D. Dietary boron: Progress in establishing essential roles in human physiology. J. Trace Elem. Med. Bio. 2012, 26, 157-160. [CrossRef]

13. Nielsen, F.H. Is boron nutritionally relevant? Nutr. Rev. 2008, 66, 183-191. [CrossRef] [PubMed]

14. Devirian, T.A.; Volpe, S.L. The physiological effects of dietary boron. Crit. Rev. Food Sci. Nutr. 2003, 43, 219-231. [CrossRef] [PubMed]

15. Nielsen, F.H. Boron in Aging and Longevity. In Trace Elements and Minerals in Health and Longevity; Springer: Cham, Switzerland, 2018; pp. 163-177.

16. Landi, M.; Margaritopoulou, T.; Papadakis, I.E.; Araniti, F. Boron toxicity in higher plants: An update. Planta 2019, 1-22. [CrossRef]

17. Marschner, H. Mineral. Nutrition of Higher Plants; Academic Press: Cambridge, MA, USA, 1995; ISBN 9780080571874. 
18. Jin, Z.; Minyan, W.; Lianghuan, W.; Jiangguo, W.; Chunhai, S. Impacts of combination of foliar iron and boron application on iron biofortification and nutritional quality of rice grain. J. Plant. Nutr. 2008, 31, 1599-1611. [CrossRef]

19. Johnson, C.M.; Stout, P.R.; Broyer, T.C.; Carlton, A.B. Comparative chlorine requirements of different plant species. Plant. Soil 1957, 8, 337-353. [CrossRef]

20. Shah, A.; Wu, X.; Ullah, A.; Fahad, S.; Muhammad, R.; Yan, L.; Jiang, C. Deficiency and toxicity of boron: Alterations in growth, oxidative damage and uptake by citrange orange plants. Ecotox Environ. Safe 2017, 145, 575-582. [CrossRef] [PubMed]

21. D'Imperio, M.; Renna, M.; Cardinali, A.; Buttaro, D.; Serio, F.; Santamaria, P. Calcium biofortification and bioaccessibility in soilless "baby leaf" vegetable production. Food Chem. 2016, 213, 149-156. [CrossRef]

22. Gonnella, M.; Renna, M.; D'Imperio, M.; Santamaria, P.; Serio, F. Iodine Biofortification of Four Brassica Genotypes is Effective Already at Low Rates of Potassium Iodate. Nutrients 2019, 11, 451. [CrossRef]

23. Montesano, F.F.; D'Imperio, M.; Parente, A.; Cardinali, A.; Renna, M.; Serio, F. Green bean biofortification for Si through soilless cultivation: Plant response and Si bioaccessibility in pods. Sci. Rep. 2016, 6, 1-9. [CrossRef]

24. Smoleń, S.; Baranski, R.; Ledwożyw-Smoleń, I.; Skoczylas, Ł.; Sady, W. Combined biofortification of carrot with iodine and selenium. Food Chem. 2019, 300, 125202. [CrossRef] [PubMed]

25. Di Gioia, F.; Petropoulos, S.A.; Ozores-Hampton, M.; Morgan, K.; Rosskopf, E.N. Zinc and Iron Agronomic Biofortification of Brassicaceae Microgreens. Agronomy 2019, 9, 677. [CrossRef]

26. Renna, M.; Castellino, M.; Leoni, B.; Paradiso, V.; Santamaria, P. Microgreens Production with Low Potassium Content for Patients with Impaired Kidney Function. Nutrients 2018, 10, 675. [CrossRef] [PubMed]

27. D’Imperio, M.; Montesano, F.F.; Renna, M.; Parente, A.; Logrieco, A.F.; Serio, F. Hydroponic Production of Reduced-Potassium Swiss Chard and Spinach: A Feasible Agronomic Approach to Tailoring Vegetables for Chronic Kidney Disease Patients. Agronomy 2019, 9, 627. [CrossRef]

28. Egea-Gilabert, C.; Ruiz-Hernández, M.V.; Parra, M.Á.; Fernández, J.A. Characterization of purslane (Portulaca oleracea L.) accessions: Suitability as ready-to-eat product. Sci. Hortic. 2014, 172, 73-81. [CrossRef]

29. Petropoulos, S.A.; Karkanis, A.; Fernandes, Â.; Barros, L.; Ferreira, I.C.; Ntatsi, G.; Khah, E. Chemical composition and yield of six genotypes of common purslane (Portulaca oleracea L.): An alternative source of omega-3 fatty acids. Plant. Foods Hum. Nutr. 2015, 70, 420-426. [CrossRef]

30. Di Gioia, F.; Renna, M.; Santamaria, P. Sprouts, microgreens and "baby leaf" vegetables. In Minimally Processed Refrigerated Fruits and Vegetables; Springer: Boston, MA, USA, 2017; pp. 403-432.

31. Renna, M.; D’Imperio, M.; Gonnella, M.; Durante, M.; Parente, A.; Mita, G.; Santamaria, P.; Serio, F. Morphological and chemical profile of three tomato (Solanum lycopersicum L.) landraces of a semi-arid mediterranean environment. Plants 2019, 8, 273. [CrossRef]

32. Montesano, F.F.; Van Iersel, M.W.; Boari, F.; Cantore, V.; D'Amato, G.; Parente, A. Sensor-based irrigation management of soilless basil using a new smart irrigation system: Effects of set-point on plant physiological responses and crop performance. Agric. Water Manag. 2018, 203, 20-29. [CrossRef]

33. D'Imperio, M.; Montesano, F.F.; Renna, M.; Leoni, B.; Buttaro, D.; Parente, A.; Serio, F. NaCl stress enhances silicon tissue enrichment of hydroponic "baby leaf" chicory under biofortification process. Sci. Hortic. 2018, 235, 258-263. [CrossRef]

34. Güneş, A.; Alpaslan, M.; Çikili, Y.; Özcan, H. Effect of zinc on the alleviation of boron toxicity in tomato. J. Plant. Nutr. 1999, 22, 1061-1068. [CrossRef]

35. Ruiz, J.M.; Rivero, R.M.; Romero, L. Preliminary studies on the involvement of biosynthesis of cysteine and glutathione in the resistance to boron toxicity in sunflower plants. Plant. Sci. 2003, 165, 811-817. [CrossRef]

36. Cervilla, L.M.; Blasco, B.; Ríos, J.J.; Romero, L.; Ruiz, J.M. Oxidative stress and antioxidants in tomato (Solanum lycopersicum) plants subjected to boron toxicity. Ann. Bot. 2007, 100, 747-756. [CrossRef]

37. Landi, M.; Pardossi, A.; Remorini, D.; Guidi, L. Antioxidant and photosynthetic response of a purple-leaved and a green-leaved cultivar of sweet basil (Ocimum basilicum) to boron excess. Environ. Exp. Bot. 2013, 85, 64-75. [CrossRef]

38. Samet, H.; Çıkılı, Y. Response of purslane (Portulaca oleracea L.) to excess boron and salinity: Physiological approach. Russ. Plant. Physiol. 2019, 66, 316-325. [CrossRef]

39. Samet, H.; Çıkılı, Y. Response of purslane (Portulaca oleracea L.) to boron toxicity. Anadolu Tarım Bilimleri Derg. 2016, 31, 448-455. [CrossRef] 
40. Blevins, D.G.; Lukaszewski, K.M. Boron in plant structure and function. Annu. Rev. Plant. Biol. 1998, 49, 481-500. [CrossRef] [PubMed]

41. Sheng, M.H.; Taper, L.J.; Veit, H.; Thomas, E.A.; Ritchey, S.J.; Lau, K.H. Dietary boron supplementation enhances the effects of estrogen on bone mineral balance in ovariectomized rats. Biol. Trace Elem. Res. 2001, 81, 29-45. [CrossRef]

42. Rouphael, Y.; Kyriacou, M.C.; Petropoulos, S.A.; De Pascale, S.; Colla, G. Improving vegetable quality in controlled environments. Sci. Hortic. 2018, 234, 275-289. [CrossRef]

43. Parks, R.Q.; Lyon, C.B.; Hood, S.L. Some effects of boron supply on the chemical composition of tomato leaflets. Plant. Physiol. 1944, 19, 404. [CrossRef]

44. Aref, F. Manganese, iron and copper contents in leaves of maize plants (Zea mays L.) grown with different boron and zinc micronutrients. Afr. J. Biotechnol. 2012, 11, 896-903.

45. Rodriguez, M.G.; Gomez-Ortega, M.; Alvarez-Tinaut, M.C. Boron, copper, iron, manganese and zinc contents in leaves of flowering sunflower plants (Helianthus annuus L.), grown with different boron supplies. Plant. Soil 1981, 62, 461-464. [CrossRef]

46. Bonilla, I.; Cadahia, C.; Carpena, O.; Hernando, V. Effects of boron on nitrogen metabolism and sugar levels of sugar beet. Plant. Soil 1980, 57, 3-9. [CrossRef]

47. Yokota, H.; Konishi, S. Effect of the formation of sugar borate complex on the growth inhibition of pollen tubes of Camellia sinensis and culture cells of Nicotiana tabacum by toxic levels of borate. Soil Sci. Plant. Nutr. 1990, 36, 275-281. [CrossRef]

48. Marschner, H. Marschner's Mineral Nutrition of Higher Plants; Academic Press: London, UK, 2012.

49. Ruiz, J.M.; Bretones, G.; Baghour, M.; Ragala, L.; Belakbir, A.; Romero, L. Relationship between boron and phenolic metabolism in tobacco leaves. Phytochemistry 1998, 48, 269-272. [CrossRef]

50. Chamacho-Cristobal, J.J.; Anzellotti, D.; Gonzàlez-Fontez, A. Changes in phenolic metabolism of tobacco plants during short-term boron deficiency. Plant. Physiol. Biochem. 2020, 40, 997-1002. [CrossRef]

51. Brown, P.H.; Hu, H. Phloem mobility of boron is species dependent: Evidence for phloem mobility in sorbitol-rich species. Ann. Bot. 1996, 77, 497-506. [CrossRef]

52. Landi, M.; Degl'Innocenti, E.; Pardossi, A.; Guidi, L. Antioxidant and photosynthetic responses in plants under boron toxicity: A review. Am. J. Agric. Biol. Sci. 2012, 7, 255-270. [CrossRef]

53. Pereira, W.E.; De Siqueira, D.L.; Martınez, C.A.; Puiatti, M. Gas exchange and chlorophyll fluorescence in four citrus rootstocks under aluminum stress. J. Plant. Physiol. 2000, 157, 513-520. [CrossRef]

54. Noonan, S.C.; Savage, G.P. Oxalate content of foods and its effect on humans. Asia Pac. J. Clin. Nutr. 1999, 8, 64-74.

55. Poeydomenge, G.Y.; Savage, G.P. Oxalate content of raw and cooked purslane. J. Food Agric. Environ. 2007, 5,124 .

56. Charfeddine, M. Miglioramento del Valore Nutrizionale di Ortaggi da Foglia del Bacino del Mediterraneo. Ph.D. Thesis, University of Bari, Bari, Italy, 2004.

57. Santamaria, P. Nitrate in vegetables: Toxicity, content, intake and EC regulation. J. Sci. Food Agric. 2006, 86, 10-17. [CrossRef]

58. Abdin, M.Z.; Kumar, P.A.; Abrol, Y.P. Biochemical basis of variability in nitrate reductase activity in wheat (Triticum aestivum L.) genotypes. Plant. Cell Physiol. 1992, 33, 951-956.

59. Riens, B.; Heldt, H.W. Decrease of nitrate reductase activity in spinach leaves during a light-dark transition. Plant. Physiol. 1992, 98, 573-577. [CrossRef] [PubMed]

60. European Union. Commission regulation (EU) No 1258/2011 of 2 December 2011 amending Regulation (EC) No 1881/2006 as regards maximum levels for nitrates in foodstuffs (Text with EEA relevance). Off. J. Eur. Union L 2011, 320, 15.

(C) 2020 by the authors. Licensee MDPI, Basel, Switzerland. This article is an open access article distributed under the terms and conditions of the Creative Commons Attribution (CC BY) license (http://creativecommons.org/licenses/by/4.0/). 